\title{
Yield-Forming Effects of Herbicide and Biostimulants Application in Potato Cultivation
}

\author{
Krystyna Zarzecka', Marek Gugała', Iwona Mystkowska ${ }^{2 *}$, Anna Sikorska ${ }^{3}$ \\ 1 Institute of Agriculture and Horticulture, Siedlce University of Natural Sciences and Humanities, ul. Prusa 14, \\ 08-110 Siedlce, Poland \\ 2 Department of Dieteties, Pope John Paul II State School of Higher Education in Biała Podlaska, ul. Sidorska \\ 95/97, 21-500 Biala Podlaska, Poland \\ 3 Department of Agriculture, The State Higher School of Vocational Education in Ciechanów, ul. Narutowicza \\ 9, 06-400 Ciechanów, Poland \\ * Corresponding author's e-mail: imystkowska@op.pl
}

\begin{abstract}
A field experiment was carried out in 2018-2020 in central-eastern Poland. The aim of the study was to determine the effect of different methods of applying herbicide and herbicide with biostimulants on the yields of dry matter, starch and protein. The experiment was established using the split-plot method, in which the first factor were two potato varieties (Oberon and Malaga), and the second factor involved five methods of applying herbicide and herbicide with biostimulants (1. control object, 2. clomazone herbicide + metribuzin, 3 . clomazone herbicide + metribuzin + PlonoStart biostimulant, 4. clomazone herbicide + metribuzin + Aminoplant biostimulant, 5. clomazone herbicide + metribuzin + Agro-Sorb-Folium biostimulant). Potato varieties and methods of herbicide and biostimulant application significantly influenced the yield of dry matter, starch and protein. The highest yields of the above-mentioned tuber components were obtained from objects 5 and 3 sprayed with herbicide with the AgroSorb-Folium and PlonoStart biostimulants. The weather conditions prevailing in the years of the research were also decisive for the yield of protein collected from the area unit.
\end{abstract}

Keywords: Solanum tuberosum L., dry matter, starch, protein, growth regulators.

\section{INTRODUCTION}

Potato (Solanum tuberosum L.) is one of the four major agricultural plants in the world and constitutes one of the six plants that have changed the world [Hobhouse 2001, Halterman et al. 2016. It is cultivated on all continents, in over 160 countries. Potato is a plant easily available on the market, with many uses: direct consumption and food processing (chips, crisps, dried), starch for the agri-food and chemical industry (starch, glucose, maltodextrins, glucose syrups, modified starches, ethanol) or feed for farm animals (fresh tubers, dried potatoes, potato protein) [Zaheer and Akhatar 2016, Javed et al. 2019]. Therefore, specific quality requirements apply to each application, which is determined by many factors, such as: variety, agrotechnical treatments, climatic and soil conditions [Bártová et al. 2009, Kahlel and Sultan 2019, Trawczyński 2021]. In modern agriculture, natural and synthetic biostimulants, which have a positive effect on the yield of potato tubers and their quality, are used more and more often [Pavlista 2011, Mystkowska 2019]. The results of many experiments show that biostimulants regulate the physiological and morphological processes of potato plants, stimulate the development of the root system [Ahmadi Lahijani et al. 2018], and strengthen the protection against abiotic stress and diseases [Bulgari et al. 2019, Głosek-Sobieraj et al. 2019], increase the total, commercial and nutrient yields and improve the quality characteristics of potato tubers [Pavlista 2011, Wierzbowska et al. 2015, Baranowska 
2018, Trawczyński 2018]. Sharma et al. [2014] found that under unfavorable weather conditions, under the influence of biostimulants, the natural defense systems that stimulate plant growth and development are activated. Trawczyński [2020], under the influence of preparations containing microelements and free amino acids [Naturamin Plus, Naturamin WSP], obtained a significant increase in the content of starch, dry matter and vitamin C. Pecio [2020] includes amino acid biostimulants among the innovative products used in plant production. Direct administration of amino acids to young plants along with nutrients increases the rate of their development and stimulates plants to increase the production of organic compounds.

The aim of the research was to evaluate the effect of herbicide and herbicide with various biostimulants on the yields of dry matter, starch and total protein of potato tubers.

\section{MATERIAL AND METHODS}

\section{Field experiment and agrotechnical treatments}

Field experiment was conducted in 2018-2020 in Poland. The study was at performed at the Agricultural Experimental Station in the Zawady $\left(52^{\circ} 03^{\prime} \mathrm{N}\right.$ and $\left.22^{\circ} 33^{\prime} \mathrm{E}\right)$ owned by the University of Natural Sciences and Humanities in Siedlce. The experiment was set up using the split-plot method as two-factor, with three replications. The first factor consisted of two potato cultivars, and the second factor involved five methods of applying the herbicide and herbicide with biostimulants against the background of the control object where no chemical treatments were applied (Table 1). The experiment was established on mineral soil classified as Haplic Luvisol [WRB 2014]. The arable layer of the soil was acidic and had a low to medium content of assimilable forms of phosphorus, potassium and magnesium (Table 2). Each year, the forecrop of potatoes was winter wheat., Natural fertilization was used in the experiment - manure in the amount of $25 \mathrm{tha}^{-1}$ (autumn) and mineral fertilization in the following doses: $100 \mathrm{~kg}$ P, $150 \mathrm{~kg} \mathrm{~K}$ (autumn) and $100 \mathrm{~kg} \mathrm{~N} \cdot \mathrm{ha}^{-1}$ (spring).

Cultivation treatments were carried out in accordance with the principles of good agricultural practice. Chemical plant protection was used against the Colorado potato beetle and late blight. Doses, dates of use and selection of preparations
Table 1. Factors of the field experiment

\begin{tabular}{|c|c|}
\hline \multicolumn{2}{|c|}{ Factor I - cultivars of potato } \\
\hline 1 & Oberon \\
\hline 2 & Malaga \\
\hline \multicolumn{2}{|c|}{$\begin{array}{l}\text { Factor II - methods of herbicide and herbicide application } \\
\text { with biostimulants (objects) }\end{array}$} \\
\hline 1 & $\begin{array}{l}\text { Control object - mechanical weeding - without } \\
\text { herbicide and biostimulants }\end{array}$ \\
\hline 2 & $\begin{array}{l}\text { Avatar } 293 \mathrm{ZC} \text { (clomazone + metribuzin) at a } \\
\text { dose of } 1.5 \mathrm{dm}^{3} \mathrm{ha}^{-1}\end{array}$ \\
\hline 3 & $\begin{array}{l}\text { Avatar } 293 \mathrm{ZC} \text { (clomazone }+ \text { metribuzin) at a } \\
\text { dose of } 1.5 \mathrm{dm}^{3} \mathrm{ha}^{-1} \text { and biostimulant PlonoStart } \\
\text { at a dose of } 2.0 \mathrm{dm}^{3} \mathrm{ha}^{-1}\end{array}$ \\
\hline 4 & $\begin{array}{l}\text { Avatar } 293 \mathrm{ZC} \text { (clomazone }+ \text { metribuzin) at a } \\
\text { dose of } 1.5 \mathrm{dm}^{3} \mathrm{ha}^{-1} \text { and biostimulant Aminoplant } \\
* * \text { at a dose of } 1.5 \mathrm{dm}^{3} \mathrm{ha}^{-1}\end{array}$ \\
\hline 5 & $\begin{array}{l}\text { Avatar } 293 \mathrm{ZC} \text { (clomazone }+ \text { metribuzin) at a } \\
\text { dose of } 1.5 \mathrm{dm}^{3} \text { ha }^{-1} \text { and biostimulant Agro-Sorb- } \\
\text { Folium }{ }^{* \star *} \text { at a dose of } 4.0 \mathrm{dm}^{3} \mathrm{ha}^{-1}\end{array}$ \\
\hline
\end{tabular}

* PlonoStart - contains: min.: $\mathrm{N}_{\text {total }}-16,4, \%, \mathrm{~K}_{2} \mathrm{O}-0,75 \%$, $\mathrm{CaO}-0,07 \%, \mathrm{MgO}-0,02 \%, \mathrm{~S}-941 \mathrm{mg} \mathrm{kg}^{-1}$, lactic acid bacteria, actinomycetes;

PlonoStart - microorganisms contained in it intensify the metabolism of organic matter in the soil and increase the availability of nutrients, improves plant development, which increases the size and quality of the crop, increases plant resistance to stress;

** Aminoplant - contains: $\mathrm{N}_{\text {total }}-9,48 \%, \mathrm{~N}_{\text {organic }}-9,2 \%$, $\mathrm{N}-\mathrm{NH}_{4}-0,88 \%, \mathrm{C}_{\text {organic }}-25 \%$, free amino acids - $11,57 \%$, organic matter $-87,7 \%$;

Aminoplant - contains as many as 18 free amino acids (the main ones are: glycine, prolamine, alanine, hydroxylupanine, glutamic acid, aspartic acid, leucine, lysine), increases the activity of many enzymes, accelerates the synthesis of proteins and sugars, increases the yield and improves its quality, increases immunity plants for stresses;

*** Agro-Sorb-Folium - contains: $\mathrm{N}_{\text {total }}-2,2 \%, \mathrm{~B}-$ $0,02 \%, \mathrm{Mn}-0,05 \%, \mathrm{Zn}-0,09 \%$, total amino acids $13,11 \%$, free amino acids - 10,66\%

Agro-Sorb-Folium - increases the intensity of photosynthesis, supports plant regeneration after stress, affects the quality and increase of yield, improves the performance of plant protection products

were consistent with the recommendations of the Ministry of Agriculture and Rural Development for agricultural practice [Recommendations for the protection of agricultural plants 2020]. The tubers were harvested in the period of full physiological maturity of the tubers, i.e. in the phase 99 according to the $\mathrm{BBCH}$ scale. During the harvest, the total tuber yield was determined and 10 potato plants were sampled for chemical analyses. The starch content was determined in the fresh mass of tubers on the Reimann WPT 3C electronic hydrostatic scales (Poland). The tuber dry matter 
Table 2. Chemical properties of the soil in field experiment

\begin{tabular}{|c|c|c|c|c|c|c|}
\hline \multirow{2}{*}{ Years } & \multicolumn{2}{|c|}{ Content of available macronutrients $\left(\mathrm{mg} \mathrm{kg}^{-1}\right)$} & \multirow{2}{*}{$\begin{array}{c}\text { Organic matter } \\
\left(\mathrm{g} \mathrm{kg}^{-1}\right)\end{array}$} & $\begin{array}{c}\text { Soil } \mathrm{pH} \\
\text { in } \mathrm{KCl}\end{array}$ & \multirow{2}{*}{$\begin{array}{c}\text { Soil } \\
\text { acidity }\end{array}$} \\
\cline { 2 - 4 } & $\mathrm{P}$ & $\mathrm{K}$ & $\mathrm{Mg}$ & 20.9 & 5.25 & acidic \\
\hline 2018 & 35.2 (low) & 102.1 (low) & 36.6 (low) & 22.3 & 5.42 & acidic \\
\hline 2019 & 61.0 (medium) & 149.0 (medium) & 61.0 (medium) & 21.1 & 5.32 & acidic \\
\hline 2020 & 60.0 (medium) & 140.0 (medium) & 51.0 (medium) & 25 & \\
\hline
\end{tabular}

content was determined according to the Polish standard using the two-stage drying method, initially at $70^{\circ} \mathrm{C}$, and then at $105^{\circ} \mathrm{C}$ [Polish Standard PN-EN 12145, 2001]. Total nitrogen content was determined in the dry weight of tubers using the Kjeldahl method on a 2300 Kjeltec Analyzer Unit. The total protein content was calculated from the total nitrogen content using the factor 6.25 [Ostrowska et al. 1991]. Yields of tuber dry matter, starch and protein were calculated as the product of the total yield and the content of individual compounds.

\section{Meteorological conditions}

During the potato vegetation period (AprilSeptember), the values of the Sielianinov hydrothermal coefficient were determined, which is a measure of the effectiveness of rainfall and air temperatures in a given month. The meteorological conditions in the years of the study were varied (Table 3). In 2018, the months of April, May and June were dry and very dry, but July and August, which determine the harvest, were relatively dry and dry. It was the most favourable season for potato yielding. Year 2019 was very dry $(\mathrm{K}=0.66)$, whereas the humidity and thermal conditions were unevenly distributed in the individual months of vegetation. Year 2020 was relatively dry, but alternating months were extremely dry, relatively humid, humid, relatively dry, which was detrimental to the accumulation of ingredients in the potato tubers.

\section{Statistical analysis}

The results of the three-year study were subjected to the variance analysis ANOVA, and the significance of the differences between the means was determined using the Tukey's test method at the significance level of $p \leq 0.05$. Statistical calculations were conducted on the basis of own algorithm written in Excel in accordance with the above-mentioned mathematical model for split-plot with two factors [Trętowski and Wójcik 1991]:

$$
Y_{i j 1}=m+a_{i}+g_{1}+e^{i 1 /}{ }_{i 1}+b_{j}+a b_{i j}+e^{i 2 /}
$$

where: $Y_{i j 1}$-value of the characteristic researched; $i$-level of A (cultivars),

$b_{j}-$ level of B (methods) in the $1^{\text {st }}$ block (replication),

$m$ - experimental mean,

$a_{i}-$ effect of $i$-level of A (cultivars),

$g_{1}$ - effect of the $1^{\text {st }}$ replication,

$e^{11 /}{ }_{i 1}-$ random effect of A (cultivars) with replications,

$b_{j}$ - effect of $j$-level of B (methods),

$a b_{i j}-$ effect of interaction of A (cultivars) and B (methods), $e^{i 2 /}{ }_{i j 1}$-random effect II.

Table 3. The value of Sielianinov's hydrothermal coefficient (K) in the growing season [Zawady Meteorological Station in Poland]

\begin{tabular}{|c|c|c|c|c|c|c|c|}
\hline \multirow{2}{*}{ Years } & \multicolumn{7}{|c|}{ Months } \\
\cline { 2 - 8 } & April & May & June & July & August & September & April-September \\
\hline 2018 & $0.88(\mathrm{~d})$ & $0.52(\mathrm{vd})$ & $0.57(\mathrm{vd})$ & $1.06(\mathrm{rd})$ & $0.86(\mathrm{~d})$ & $1.69(\mathrm{rh})$ & $0.93(\mathrm{~d})$ \\
\hline 2019 & $0.20(\mathrm{ed})$ & $1.44(\mathrm{o})$ & $0.67(\mathrm{vd})$ & $0.51(\mathrm{vd})$ & $0.71(\mathrm{~d})$ & $0.41(\mathrm{vd})$ & $0.66(\mathrm{vd})$ \\
\hline 2020 & $0.23(\mathrm{ed})$ & $1.74(\mathrm{rh})$ & $2.05(\mathrm{~h})$ & $1.15(\mathrm{rd})$ & $0.29(\mathrm{ed})$ & $0.83(\mathrm{~d})$ & $1.05(\mathrm{rd})$ \\
\hline
\end{tabular}

$K=10 P / \Sigma t$, Skowera et al. [2014]

where: $P$ - the sum of the monthly rainfalls in $\mathrm{mm}, \Sigma t-$ monthly total air temperature $>0{ }^{\circ} \mathrm{C}$

Ranges of values of this coefficient were classified as follows: up to 0.4 - extremely dry (ed), $0.41-0.7$ - very dry (vd), 0.71-1.0 - dry (d), 1.01-1.3 - relatively dry (rd), 1.31-1.6 - optimal (o), 1.61-2.0 - relatively humid (rh), 2.01-2.5 - humid (h), 2.51-3.0 - very humid (vh), above 3.0 - extremely humid (eh). 
Linear correlation coefficients were also calculated and the regression equations were determined between the dry matter yield of tubers, the yield of starch and total protein.

\section{RESULTS AND DISCUSSION}

The amount of nutrient yields for potato tubers, i.e. tuber dry matter, starch and protein yield, is mainly determined by the weight of the harvested tubers and the content of the above-mentioned components, which can be significantly modified by agrotechnical treatments and environmental conditions [Barbaś and Sawicka, 2016]. The conducted research showed that the dry matter yield of tubers significantly depended on the cultivar and the methods of herbicide and herbicide application with biostimulants (Tables 4, 5).

The Oberon cultivar had much higher yield than the Malaga cultivar. The influence of genetic characteristics of varieties on the content and yields of dry matter and starch of potato tubers was reported by Barbaś and Sawicka [2016], Kahlel and Sultan [2019], Mystkowska [2019], Trawczyński [2021]. Herbicide and herbicide with biostimulants significantly increased the dry matter yield of tubers in comparison to the control object. The best results were obtained after the combined application of the Avatar 293 ZC preparation and Agro-Sorb-Folium biostimulant - the dry matter yield was $33 \%$ higher compared to the object tended only mechanically. The main reason for increasing the yield on the objects sprayed with herbicides and biostimulants was the reduction of weed infestation (limiting the competition of weeds), and at the same time stimulating the effect of Agro-Sorb-Folium, PlonoStart and Aminoplant on the growth and development of potato plants. Baranowska [2018] obtained a $40 \%$ increase in the dry matter yield of tubers after applying the Avatar 293 ZC herbicide and spraying three times with the GreenOK Universal-PRO biostimulant. The research by Zarzecka et al. [2021] also confirmed the positive effect of

Table 4. Yields of dry matter, starch and protein of potato tubers $\left(\mathrm{t} \mathrm{ha} \mathrm{h}^{-1}\right)$

\begin{tabular}{|c|c|c|c|}
\hline \multirow{2}{*}{$\begin{array}{c}\text { Methods of herbicide and herbicide application with } \\
\text { biostimulants }\end{array}$} & \multicolumn{2}{|c|}{ Cultivars } & \multirow{2}{*}{ Mean } \\
\hline & Oberon & Malaga & \\
\hline \multicolumn{4}{|c|}{ Tuber dry matter yield } \\
\hline 1. Control object & $7.30 \mathrm{~A}$ & $5.03 \mathrm{~A}$ & $6.17 d$ \\
\hline 2. Avatar $293 \mathrm{ZC}$ & $7.81 \mathrm{~A}$ & $5.98 \mathrm{~A}$ & $6.90 c$ \\
\hline 3. Avatar 293 ZC + PlonoStart & $8.78 \mathrm{~A}$ & $6.37 \mathrm{~A}$ & $7.58 b$ \\
\hline 4. Avatar 293 ZC + Aminoplant & $8.38 \mathrm{~A}$ & $6.15 \mathrm{~A}$ & $7.27 \mathrm{bc}$ \\
\hline 5. Avatar 293 ZC + Agro-Sorb-Folium & $9.46 \mathrm{~A}$ & 7.03A & $8.24 a$ \\
\hline Mean & $8.35 a$ & $6.11 \mathrm{~b}$ & 7.23 \\
\hline \multicolumn{4}{|c|}{ Starch yield } \\
\hline 1. Control object & $4.05 \mathrm{C}$ & $2.84 \mathrm{~B}$ & $3.44 d$ \\
\hline 2. Avatar $293 \mathrm{ZC}$ & 4.39BC & $3.44 \mathrm{AB}$ & $3.92 \mathrm{c}$ \\
\hline 3. Avatar 293 ZC + PlonoStart & $4.96 \mathrm{~A}$ & $3.70 \mathrm{~A}$ & $4.33 b$ \\
\hline 4. Avatar 293 ZC + Aminoplant & 4.87AB & $3.59 \mathrm{~A}$ & $4.24 \mathrm{bc}$ \\
\hline 5. Avatar 293 ZC + Agro-Sorb-Folium & $5.48 \mathrm{~A}$ & $4.09 \mathrm{~A}$ & $4.79 a$ \\
\hline Mean & $4.75 a$ & $3.53 b$ & 4.14 \\
\hline \multicolumn{4}{|c|}{ Protein yield } \\
\hline 1.Control object & $1.07 \mathrm{~A}$ & $0.56 \mathrm{~A}$ & $0.82 d$ \\
\hline 2. Avatar $293 \mathrm{ZC}$ & $1.18 \mathrm{~A}$ & $0.73 \mathrm{~A}$ & $0.96 \mathrm{~cd}$ \\
\hline 3. Avatar 293 ZC + PlonoStart & $1.48 \mathrm{~A}$ & $0.81 \mathrm{~A}$ & $1.15 \mathrm{ab}$ \\
\hline 4. Avatar 293 ZC + Aminoplant & $1.33 \mathrm{~A}$ & $0.77 \mathrm{~A}$ & $1.05 \mathrm{bc}$ \\
\hline 5. Avatar 293 ZC + Agro-Sorb-Folium & $1.55 \mathrm{~A}$ & $0.88 \mathrm{~A}$ & $1.22 a$ \\
\hline Mean & $1.32 a$ & $0.75 b$ & 1.04 \\
\hline
\end{tabular}

Means followed by the same letters do not differ significantly at $\mathrm{p} \leq 0.05$. Means in columns marked with capital letters refer to interactions between the factors. Means in the last column and means in the last row (followed by lowercase) are for methods and cultivars. 
Table 5. Yields of dry matter, starch and protein of potato tubers in study years $\left(\mathrm{t} \mathrm{ha}^{-1}\right)$

\begin{tabular}{|c|c|c|c|}
\hline \multirow{2}{*}{ Years } & \multicolumn{2}{|c|}{ Cultivars } & \multirow{2}{*}{ Mean } \\
\cline { 2 - 3 } & Oberon & Malaga & \\
\hline \multicolumn{3}{|c|}{ Tuber dry matter yield } \\
\hline 2018 & $9.77 \mathrm{~A}$ & $5.63 \mathrm{~A}$ & $7.70 \mathrm{a}$ \\
\hline 2019 & $8.17 \mathrm{~A}$ & $6.62 \mathrm{~A}$ & $7.40 \mathrm{a}$ \\
\hline 2020 & $7.10 \mathrm{~A}$ & $6.09 \mathrm{~A}$ & $6.59 \mathrm{a}$ \\
\hline Mean & $8.35 \mathrm{a}$ & $6.11 \mathrm{~b}$ & 7.23 \\
\hline \multicolumn{4}{|c|}{ Starch yield } \\
\hline 2018 & $5.39 \mathrm{~A}$ & $3.18 \mathrm{~A}$ & $4.29 \mathrm{a}$ \\
\hline 2019 & $4.71 \mathrm{~B}$ & $3.73 \mathrm{~A}$ & $4.22 \mathrm{a}$ \\
\hline 2020 & $4.15 \mathrm{~B}$ & $3.69 \mathrm{~A}$ & $3.92 \mathrm{a}$ \\
\hline Mean & $4.75 \mathrm{a}$ & $3.53 \mathrm{~b}$ & 4.14 \\
\hline \multicolumn{5}{|c|}{ Protein yield } \\
\hline 2018 & $1.65 \mathrm{~A}$ & $0.68 \mathrm{~A}$ & $1.17 \mathrm{a}$ \\
\hline 2019 & $1.16 \mathrm{~B}$ & $0.81 \mathrm{~A}$ & $0.99 \mathrm{~b}$ \\
\hline 2020 & $1.15 \mathrm{~B}$ & $0.77 \mathrm{~A}$ & $0.96 \mathrm{~b}$ \\
\hline Mean & $1.32 \mathrm{a}$ & $0.75 \mathrm{~b}$ & 1.04 \\
\hline
\end{tabular}

Means followed by the same letters do not differ significantly at $\mathrm{p} \leq 0.05$. Means in columns marked with capital letters refer to interactions between the factors. Means in the last column and means in the last row (followed by lowercase) are for cultivars and years.

herbicides and herbicides with biostimulants on the content and yield of dry matter. Wierzbowska et al. [2015] demonstrated the beneficial effect of Asahi SL, Bio-Algeen S90 and Kelpak growth stimulants on potato yielding. The positive effect of treating plants with biostimulants on the yield parameters of Capsicum annuum L. was also observed by Parađiković et al. [2011].

The starch yield was determined by the genetic characteristics of the cultivars and the methods of using the herbicide and herbicide with biostimulants (Tables 4, 5). The Oberon cultivar was characterized by a starch yield higher by $1.22 \mathrm{t} \mathrm{ha}^{-1}$ than the cultivar Malaga. Varietal differences in terms of starch yield were also noted by Gugała and Zarzecka [2010], Pszczółkowski et al. [2016], Zarzecka et al. [2021]. Statistical calculations showed that the starch yield was determined with the methods of using the herbicide and biostimulants. The highest yields of this component in relation to the control object were obtained after the application of the Avatar 293 ZC herbicide and Agro-Sorb-Folium biostimulant. Significantly higher yields were also collected from the plots where the herbicide and other biostimulants were applied. Baranowska
[2018] also noted a significant effect of herbicide and biostimulants on this trait. Studies by other researchers indicate higher starch yields after the application of growth regulators [Trawczyński 2018, Mystkowska 2019]. On the other hand, in the studies by Barbaś and Sawicka [2016], there was no significant effect of weed control methods on the starch yield, but the authors proved a significant interaction of varieties with weed control methods.

The analysis of variance showed that the protein yield was determined by the cultivars, the methods of applying herbicide and herbicide with biostimulants, as well as the humidity and thermal conditions in the study years (Tables 4, 5). A higher yield of total protein, as well as dry matter and starch, was noted in the Oberon variety compared to the Malaga variety. The influence of the variety on this trait was confirmed by the research of Wierzbicka and Trawczyński [2012]. When analysing the methods of herbicide and herbicide application with biostimulants, it was found that on 3-5 objects sprayed with the Ava$\operatorname{tar} 293$ ZC herbicide and PlonoStart, Aminoplant and Agro-Sorb-Folium biostimulants, the protein yield was significantly higher compared to the control object. Thus, there were similar trends as in the yield of dry matter and starch. Baranowska et al. [2018] also showed a significant effect of herbicide and biostimulants on the yield of total potato protein. After the application of herbicides to weed potatoes, Gugała and Zarzecka [2010] noted an increase in the yield of total protein and proper protein compared to the object without chemical treatments.

The weather conditions during the research had an impact on the parameters of the total protein yield of potato tubers. The highest yields of this nutrient were obtained in 2018, which was dry, but July and August favoured tuber formation, nutrient accumulation and yielding. On the other hand, the yields were significantly lower in the remaining years of the experiment. A similar effect of the weather factor on the protein yield was also reported by other researchers [Bártová et al. 2009, Gugała and Zarzecka 2010, Baranowska et al. 2018]. The calculated linear correlation coefficients and regression coefficients showed that potato tuber dry matter yields, starch yields and total protein yields were strongly correlated (Table 6).

When the dry matter yield increased by 1 ton, the starch yield increased by 0.65 tons and protein by 0.20 tons. An increase in the starch yield 
Table 6. Correlation and regression analysis among yields of dry matter, starch and protein of potato

\begin{tabular}{|c|c|c|c|}
\hline Characteristic & Tuber dry matter yield & Starch yield & Protein yield \\
\hline Tuber dry matter yield & 1.000 & $0.9965^{\star}$ & $0.9881^{*}$ \\
\hline Starch yield & & 1.000 & $0.9814^{*}$ \\
\hline Protein yield & & & 1.000 \\
\hline \multicolumn{4}{|c|}{ Regression analysis } \\
\hline \multicolumn{2}{|c|}{ Dependence } & \multicolumn{2}{|c|}{ Regression equation } \\
\hline \multicolumn{2}{|c|}{ Among tuber dry matter yield $(\mathrm{x})$ and starch yield $(\mathrm{y})$} & \multicolumn{2}{|c|}{$y=0.65 \cdot x-0.55$} \\
\hline \multicolumn{2}{|c|}{ Among tuber dry matter yield $(\mathrm{x})$ and protein yield $(\mathrm{y})$} & \multicolumn{2}{|c|}{$y=0.20 \cdot x-0.42$} \\
\hline \multicolumn{2}{|c|}{ Among starch yield $(\mathrm{x})$ and protein yield $(\mathrm{y})$} & \multicolumn{2}{|c|}{$y=0.31 \cdot x-0.24$} \\
\hline
\end{tabular}

* Highly significant $(\mathrm{p} \leq 0.05)$.

by 1 ton increased the protein yield by 0.31 tons. The obtained results were confirmed in the research by Wierzbicka and Trawczyński [2012], who, on the basis of correlation and regression analysis, showed that the higher the dry matter yield, the higher the protein yield. Bártová et al. [2009] noted positive significant correlations between the yield of potato tubers and the yield of dry matter and the yield of protein. Mystkowska [2019] found that the volume of starch yield is the resultant of the tuber yield and the starch concentration in potatoes. In the conducted research, the content of dry matter, starch and protein in potato tubers significantly depended on the cultivars and methods of herbicide and herbicide application with biostimulants (Table 7).

Moreover, in earlier studies by Zarzecka et al. [2021], the content and yield of starch depended on the cultivar and weed control methods. The authors obtained the highest values of these features after the application of the Sencor 70 WG herbicide and the Asahi SL biostimulant. Wierzbicka and Trawczyński [2012] proved that there was a linear relationship between the protein content and the yield of this component. The protein yield was the higher the higher the protein content.

Table 7. The results of variance analysis of the dry matter, starch and protein content

\begin{tabular}{|c|c|c|c|}
\hline \multirow{2}{*}{ Characteristic } & \multicolumn{3}{|c|}{ Significance of the influence } \\
\cline { 2 - 4 } & Cultivars & Methods & Years \\
\hline Dry matter & $\mathrm{x}$ & $\mathrm{x}$ & $\mathrm{x}$ \\
\hline Starch & $\mathrm{x}$ & $\mathrm{x}$ & - \\
\hline Protein & $\mathrm{x}$ & $\mathrm{x}$ & $\mathrm{x}$ \\
\hline
\end{tabular}

$\mathrm{x}-$ significant at $\mathrm{p} \leq 0.05$.

\section{CONCLUSIONS}

The cultivars grown in the experiments determined the dry matter yields of potato tubers, starch and total protein. Higher yields of these ingredients were found in the Oberon variety, compared to the Malaga variety.

The use of herbicide and herbicide with biostimulators for the care of potato plantations significantly increased the yields of the discussed tuber components compared to the control object weeded only mechanically. The highest yields of dry matter, starch and protein were obtained from objects sprayed with the Avatar 393 ZC herbicide with Agro-Sorb-Folium and PlonoStart biostimulants. Biostimulants increased the yielding effect and thus their use can be considered a good production strategy. These preparations should find wider application in agricultural practice.

\section{Acknowledgments}

The research was carried out under the research project No. 31/20/B financed from a science grant by the Ministry of Science and Higher Education of Poland.

\section{REFERENCES}

1. Ahmadi Lahijani M.J., Kafi M., Nezami A., Nabati J., Erwin J. 2018. Effect of 6-benzylaminopurine and abscisic acid on gas exchange, biochemical traits, and minituber production of two potato cultivars (Solanum tuberosum L.). Journal of Agricultural Science and Technology, 20, 129-139.

2. Baranowska A.J. 2018. Yield of dry matter and starch of edible potato tubers in conditions of application of growth biostimulators and herbicide. Acta Agrophysica, 25(4), 397-407. https://doi.org/10.31545/aagr/99073 
3. Baranowska A., Mystkowska I., Zarzecka K., Szczygielska E. 2018. Impact of growth biostimulators and herbicide on the content of major protein in edible potato tubers. Journal of Ecological Engineering, 20(3), 262-269. https://doi. org/10.12911/22998993/102610

4. Barbaś P., Sawicka, B. 2016. The influence of methods of weed control on the content and the yield of dry matter and starch in the tubers two cultivars of potato. Fragmenta Agronomica, 33(4), 7-17. (in Polish)

5. Bártová V., Bárta J., Diviš J., Švajner J., Peterka J. 2009. Crude protein content in tubers of starch processing potato cultivars in dependence on different agro-ecological conditions. Journal Central European Agriculture, 10(1), 57-66.

6. Bulgari R., Franzoni G., Ferrante A. 2019. Biostimulants application in horticultural crops under abiotic stress conditions. Agronomy, 9(306), 1-30. https://doi.org/10.3390/agronomy9060306

7. Gugała M., Zarzecka K. 2010. The influence of herbicides on content of dry matter, protein and starch in potato tubers. Biuletyn Instytutu Hodowli i Aklimatyzacji Roślin, 257/258, 111-119. (in Polish)

8. Głosek-Sobieraj M., Cwalina-Ambroziak B., Waśkiewicz A., Hamouz K., Perczak A. 2019. The effect of biostimulants on the health status and content of chlorogenic acids in potato tubers (Solanum tuberosum L.) with colored flesh. Gesunde Pflanzen. https://doi.org/10.1007/s10343-018-00441-7

9. Halterman G., Guenthner J., Collinge S., Butler N., Douches D. 2016. Biotech Potatoes in the 21st Century: 20 Years Since the First Biotech Potato. American Journal of Potato Research, 93, 1-20. https://doi.org/10.1007/s12230-015-9485-1

10. Hobhouse H. 2001. The seeds of change - six plants that changed the face of the world. Issued by Warsaw Literary Publishing House. Warsaw, Poland, 482. (in Polish)

11. Javed A., Ahmad A., Tahir A., Shabbir U., Noumanand M., Hameed A. 2019. Potato peel waste - its nutraceutical, industrial and biotechnological applacations. Agriculture and Food, 4(3), 807-823. https://doi.org/10.3934/agrfood.2019.3.807

12. Kahlel A.M.S., Sultan F.I. 2019. Response of four potato cultivars to soil application with organic and amino acid compounds. Research On Crops, 20(1), 101-108.

13. Mystkowska I. 2019. Biostimulators as a factor affecting the dry matter yield and starch content of edible potato tubers. Acta Agrophysica, 26(1), 37-45. https://doi.org/10.31545/aagr/10853536: 45-53

14. Ostrowska A., Gawlinski S., Szczubiałka Z. 1991. Methods of Analysis and Assessment of Soil and Plant Properties. Issued by Institute of Environment Protection. Warsaw, Poland, 334. (in Polish)
15. Parađiković N., Vinković T., Vinković Vrček I., Žuntar I., Bojić M., Medić-Šarić M. 2011. Effect of natural biostimulants on yield and nutritional quality: an example of sweet yellow pepper (Capsicum annuum L.) plants. Journal of the Science of Food Agriculture, 91(12), 2146-2152. https://doi. org/10.1002/jsfa.4431

16. Pavlista A.D. 2011. Growth regulators increased yield of Atlantic potato. American Journal of Potato Research, 88, 479-484.

17. Pecio A. 2020. Innovative products used in plant production. Studia i Raporty IUNG-PIB, 63(17): 163-178. https://doi.org/10.26114/sir. iung.2020.63.11 (in Polish)

18. Polish Norm PN-EN 12145. 2001. Fruit and Vegetable Juices - Determination of Dry Matter - Gravimetric Method. The Polish Committee for Standardization. Warsaw, Poland. (in Polish)

19. Pszczółkowski P., Sawicka B., Lenartowicz T. 2016. Effect of irrigation several selected cultivars of potato on the yield and starch content in three region of Poland. Fragmenta Agronomica, 33(3), 65-79. (in Polish)

20. Recommendations for the protection of agricultural plants. 2020. Issued by Institute of Plant Protection-National Research Institute, Poznań, Poland. (in Polish)

21. Sharma H.S., Fleming C., Selby C., Rao J.R., Martin T. 2014. Plant Biostimulants: A Review on the Processing of Macroalgae and Use of Extracts for Crop Management to Reduce Abiotic and Biotic Stresses. Applied Phycology, 26, 465-490. http:// dx.doi.org/10.1007/s10811-013-0101-9

22. Skowera B., Jedrszczyk E.S., Kopcinska J., Ambroszczyk A.M., Kołton A. 2014. The effects of hydrothermal conditions during vegetation period on fruit quality of processing tomatoes. Polish Journal of Environmental Studies, 23, 195-202.

23. Trawczyński C. 2018. The effect of foliar preparation with silicon on the yield and quality of potato tubers in compared to selected biostimulators. Fragmenta Agronomica, 5(4), 113-122. https://doi. org/10.26374/fa.2018.35.47

24. Trawczyński C. 2020. The effect of biostimulators on the yield and quality of potato tubers grown in drought and high temperature conditions. Biuletyn Instytutu Hodowli i Aklimatyzacji Roślin 289: 11-19. https://doi.org/10.37317/biul-2020-0017 (in Polish)

25. Trawczyński C. 2021. Assessment of mineral nitrogen fertilization of early potato varieties in integrated production. Journal of Elementology, 26(1), 109123. https://doi.org/10.5601/jelem.2020.25.4.2066

26. Trętowski J., Wójcik R. 1991. Methodology of agricultural experiments. Issued by Wyższa Szkoła Rolniczo-Pedagogiczna, Siedlce, Poland, 500. (in Polish) 
27. Wierzbicka A., Trawczyński C. 2012. Factors affecting the protein content and protein yield in potato tubers. Biuletyn Instytutu Hodowli i Aklimatyzacji Roślin, 266, 181-190. (in Polish)

28. Wierzbowska J., Cwalina-Ambroziak B., GłosekSobieraj M., Sienkiewicz S. 2015. Effect of biostimulators on yield and selected chemical properties of potato tubers. Journal of Elementology 20(3): 757-768. https://doi.org/10.5601/ jelem.2014.19.4.799

29. WRB 2014. World reference base for soil resources 2014. International soil classification system for naming soils and creating legends for soil maps. World Soil Resources Reports No. 106. FAO, Rome, Italy, 203

30. Zaheer K., Akhatar M.H. 2016. Potato Production, Usage, and Nutrition - A Review. Critical Reviews in Food Science and Nutrition, 56(5), 711-721. https://doi.org/10.1080/10408398.2012.724479

31. Zarzecka K., Gugała M., Mystkowska I., Sikorska A. 2021. Changes in dry weight and starch content in potato under the effect of herbicides and biostimulants. Plant, Soil and Environment, 67(4), 202-207. https://doi.org/10.17221/622/2020-PSE 